\title{
Screening of Endophytic Bacteria as Biocontrol Agents Against Bacteria Leaf Blight (Xanthomonas oryzae)
}

\author{
Rashidah Abd Halim ${ }^{1,2}$, Nor'Aishah Hasan ${ }^{1 *}, K_{\text {Kogeethavani Ramachandran }}^{3}$ \\ ${ }^{1}$ Faculty of Applied Sciences, Universiti Teknologi MARA, Cawangan Negeri Sembilan, Kuala Pilah Negeri Sembilan, Malaysia \\ ${ }^{2}$ Faculty of Applied Sciences, Universiti Teknologi MARA, Shah Alam, Selangor, Malaysia \\ ${ }^{3}$ Laboratory of Plant Pathology, Rice and Industrial Crops Research Centre, MARDI Seberang Perai, Kepala Batas, Penang, Malaysia
}

\section{ARTICLE INFO}

Article history:

Received October 30, 2019

Received in revised form May 15, 2020

Accepted May 30, 2020

\section{KEYWORDS:}

Endophytic bacteria,

biocontrol agent,

Geobacillus thermoparaffinivorans,

Pseudomonas fluorescens,

Xanthomonas oryzae pv. oryzae

\begin{abstract}
Bacterial leaf blight (BLB) is one of major threats in rice production as it can cause $\mathbf{1 0 0 \%}$ yield loss. Concern on the environment and human health has led an attempt to replace existing methods of chemical control and avoid extensive use of bactericides by using endophytic bacteria. The present study was conducted to screen and characterize bacteria isolated from different sources that has potential as antagonistic bacteria against Xanthomonas oryzae pv. oryzae (Xoo), the causal agent of bacterial leaf blight of paddy. Two hundred and thirty-three endophytic bacteria were successfully isolated from roots and leaves from paddy field. Only 17 endophytic bacterial isolates showed positive antagonistic activity indicated by inhibition zone around bacterial colony against $X o o$ on nutrient agar plate with 2 endophytic isolates (BCA 3 and BCA 12) showed highest inhibitory effect with $35 \pm 0.00 \mathrm{~mm}$ in diameter. Molecular identification by $16 \mathrm{~S}$ rRNA amplification successfully identified the antagonistic endophytic bacteria as Pseudomonas fluorescens and Geobacillus thermoparaffinivorans. Findings in this study revealed the biocontrol abilities of isolated endophytes as an excellent option to be used by agriculture sectors to have sustainable environment.
\end{abstract}

\section{Introduction}

Rice is the most important food crop of the developing world and the staple food of more than half of the world's population. More than $90 \%$ of rice is produces and consumed in Asia. In Malaysia, rice is cultivated on 8 major granary area with average rice consumption by Malaysian citizen is about 82.3 kilograms per year (Raweekul and Wuttitummaporn 2016). However, the average growth rate of rice yield in Malaysia was decreased due to the infection of rice plant from the microbial disease's incidence. Bacteria leaf blight (BLB) caused by Xanthomonas oryzae has recently become a common disease among rice crop in Malaysia. Moist conditions at the beginning of the season is the major factor enable the bacteria to grow from infected stubble to an adjacent seedling (Hogg et al. 2010). Farmers often heavily rely on using chemical bactericides to control these plant diseases as well as enhance

* Corresponding Author

E-mail Address: aishahnh@uitm.edu.my the plant health. Unfortuntely, the continuing used of synthetic bactericides in agriculture have led to public concern on human and environmental health. Widely and extensive use of chemical bactericides has become a main environmental threat when its drivers to species extinction, leads to the reduction of global biodiversity and caused significant changes in ecosystem dynamics (Aktar et al. 2009).

Recently certain potential biocontrol agents such as Bacillus amyloliquefaciens, Bacillus methylotrophicus and Bacillus subtilis were isolated from rice plants showing the significant antimicrobial activities against Rhizoctonia solani and Burkholderia glumae, the two major rice pathogens that cause sheath blight and bacterial panicle blight diseases (Shrestha et al. 2016). For these and other reasons, nowadays endophytic bacteria are widely investigated by researcher to develop a sustainable environmentally friendly, microbial-based biocontrol agent as an alternative to agrochemicals.

Potential endophytic microorganisms are mainly consisting of bacteria and fungi that colonize inner 
part of plant tissues without causing any damage to their host plant (Schulz and Boyle 2006). The colonization of these endophytic microorganisms can be isolated from surface sterilized monocotyledonous and dicotyledonous plants (Hallmann et al. 1997). The main gateway for endophytes to penetrate the plant's tissues is from the root zone, but the earlier study also proved that endophytes also can invade through the aerial tissues of the host plant (chi et al. 2005). The pathways of endophytes also include the natural vents and wounds found at the plant tissues (Hallmann et al. 1997). Besides that, the microscopic opening such as stomata is a critical first step of the microbial entrance into host tissues (Schulze and Robatzel 2006).

Therefore the aim of the present study was to isolate and identify endophytic bacteria from commonly used rice cultivars in Malaysia, in order to evaluate their effect as biocontrol agents against rice bacterial blight caused by Xanthomonas oryzae pv. oryzae (Xoo).

\section{Materials and Methods}

\subsection{Pathogen Inoculum Preparation}

The Xoo strain (MXO 1410) was obtained from Laboratory of Plant Pathology, Rice and Industrial Crops Research Centre, MARDI Seberang Perai, Malaysia. The strain was sub-cultured in Potato Sucrose Agar (PSA) plate and in PSA agar slant for long term preservation in $20 \%$ glycerol and keep in $-80^{\circ} \mathrm{C}$. For inoculums preparation, the Xanthomonas (Xoo) culture was inoculated on PS broth media and incubated at $30^{\circ} \mathrm{C}$ for 48 hours. Then the Xoo culture was diluted with sterile distilled water. Cell suspensions containing $10^{8}$ colony forming units (cfu) of Xanthomonas oryzae pv. oryzae using a spectrophotometer at $600 \mathrm{~nm}$ wavelength with 0.6 optical density volume was used (Azman et al. 2017).

\subsection{Rice Plant Sampling Materials}

Three-month-old of rice plants samples was randomly collected from three different rice fields in Pendang (Kedah), Teratak Pulai (Kelantan), and Seberang Prai (Pulau Pinang). The whole rice plant will be carefully uprooted and place in a sterile plastic bag, label and tied and further put in a box containing ice (Raweekul and Wuttitummaporn 2016).

\subsection{Endophytic Bacterial Isolation}

The roots and leaves were washed with slow running tap water and then cut into small pieces. The surface of the leaves and roots performed surface sterilized by using $10 \%(\mathrm{v} / \mathrm{v})$ of Sodium Hypochlorite and a few drops of Tween-20 was added. The samples were rinsed with the sterilized distilled water five times and then a mortar and a pestle were used to ground the tissues and obtain the bacterial suspension. Serial dilutions were done from the suspension and the concentration were prepared up to $10^{-3}$, then the sample was streaked on nutrient agar (NA) and incubated at $30^{\circ} \mathrm{C}$ for 7 days. Water that was used for the final rinse was kept to plate on NA plates to act as a control (Raweekul and Wuttitummaporn 2016). Isolated endophytic bacteria were plated on Nutrient agar medium after performed serial dilution method as mentioned by (Yasmin et al. 2017). The purified isolated bacteria strain was stored in NA slants at $4^{\circ} \mathrm{C}$ and in $-20^{\circ} \mathrm{C}$ for further used.

\subsection{Antagonistic Bacteria Screened}

The inhibition of Xoo were screened in vitro by well diffusion method as described by (Abdulkadir and Waliyu 2012). The fresh culture of Xoo was spread on TSA media. The isolated bacteria strain that was grown on Nutrient broth for screened of antagonistic activity were spotted about $60 \mu$ in the well on TSA plates that already spread with Xoo strain. The plates were kept in the incubator at $30^{\circ} \mathrm{C}$ for $24 \mathrm{~h}$ and the clear zone of inhibition was recorded by measuring the diameter (Yasmin et al. 2017).

\subsection{Antagonistic Bacteria Identification by Using Molecular Method}

The antagonistic endophytes grown in Nutrient Broth and incubated at $37^{\circ} \mathrm{C}$ for 2 days. The DNA of each endophytes was extracted using RBC HiYield ${ }^{\mathrm{TM}}$ Genomic DNA Mini Kit (Bacteria) as per manufacturer instruction. The DNA was amplified by Mastercycler ${ }^{\circledR}$ NexusGradientmachineforpolymerasechain reaction amplification. The gene fragments of antagonistic endophytes were sequenced using universal primers pair 518F (5'-CCAGCAGCCGCGGTAATACG3') and 800R (5'TACCAGGGTATCTAATCC-3') that was synthesised by MYTACG Bioscience Enterprise, Malaysia. The 50 $\mu$ of PCR reaction mixture contained $5 X$ Green GoTaq 
(5 $\mu \mathrm{l})$, dNTPs $(1 \mu \mathrm{l})$, Forward primer $(1 \mu \mathrm{l})$, Reverse primer $(1 \mu \mathrm{l}$, genomic DNA $(2 \mu \mathrm{l})$, Taq Polymerase $(0.5$ $\mu \mathrm{l})$ and nucleus free water $(39.5 \mu \mathrm{l})$ modified from Azman et al. (2017) method. Amplifications of gene was performed for 30 cycles in Eppendorf gradient thermal cyclers programmed (Kathleen 2006). The reaction will proceed as follows: 1 cycle for 3 minutes at $94^{\circ} \mathrm{C}$ (Denature), 40 cycles for 1 minutes at $94^{\circ} \mathrm{C}$ (Denature), followed by $50^{\circ} \mathrm{C}$ for 1 minutes (Anneal) and 1 minutes at $72^{\circ} \mathrm{C}$ (Elongation).

The PCR product was proceeded for Gel Electrophoresis, $1 \%$ agarose gel was used by preparing 1 g agarose powder with $100 \mathrm{ml} 1$ XTBE buffer then was stained with $2.5 \mu$ DNA Gel Stain. Gel was visualized by using Bio Rad ${ }^{\mathrm{TM}}$ gel documentation system under UV light to observe the DNA band, $1 \mathrm{~kb}$ and $100 \mathrm{bp}$ of ladder acted as marker. The sequencing process was submitted to MYTACG Bioscience Enterprise for outside services. The pairwise alignment analysis of partial 16S rRNA gene sequences was performed on the MEGA X database (Kim et al. 2012). The 16S rRNA gene sequences of known bacterial species were subjected to Basic Local Alighment Search Tool (BLAST) for identification and all obtained sequence were submitted to NCBI GenBank database (Azman et al. 2017).

\subsection{Control of Bacterial Leaf Blight Disease under Greenhouse Conditions}

The rice seeds from variety MR284 was performed seed bacterization using $2 \%$ sodium hypochlorite for 30 second, rinsed with sterile distilled water and lastly was dried overnight. The seeds were soaked in potential endophytes suspension for 2 hours before kept it dried under shade. The treated seeds were sown in pots along with the untreated seeds that acted as control. At day 22 after sowing, the positive control of plant was sprayed with chemical bactericide and negative control were sprayed with sterile distilled water (Krishnan and Muthurajab 2014). At 30 days after sowing, the leaves were clip inoculated with sterile scissors that was dipped in $10^{8} \mathrm{cfu} \mathrm{ml}^{-1}$ of $\mathrm{Xoo}$, then the treated plants were covered with a polythene bag. At 14 days after clip inoculation, the effectiveness of the treatments on bacterial leaf blight disease intensity was observed using $0^{-9}$ scale followed the Standard Evaluation System for rice (IRRI). The disease severity was calculated using formula:

$P D I=\frac{\text { Sum of all numerical ratings }}{\text { Total number of leaves graded }} \times \frac{100}{\text { Maximum grade }}$
In addition, the biocontrol effect of potential endophytes against Xanthomonas oryzae like disease severity and suppression efficacy were collected at different time intervals were collected from the following treatments.

Treatment 1: Xoo

Treatment 2: $X 00+$ Chemical bactericide

Treatment 3: Xoo + Enterobacter sp.

Treatment 4: Xoo + Bacillus subtilis

Treatment 5: Xoo + Bacillus cereus

Treatment 6: Xoo + Gamma proteobacterium

Treatment 7: Xoo + Pseudomonas fluorescent

Treatment 8: Xoo + Geobacillus thermoparaffinivorans

\subsection{Statistical Analysis}

All collected data were analysed by Statistical Package for Social Sciences (SPSS, version 23). The data were subjected to the analysis of variance (ANOVA). A completely randomized design was used for all the experiments, with 3 replications for each treatment. Differences between experimental outcomes were analysed using Tukey's HSD test and $\mathrm{p} \leq 0.05$ was considered significantly different.

\section{Results}

\subsection{Isolation of Potential Endophytes}

Three different rice field in Kedah, Kelantan, and Pulau Pinang were selected in this study to evaluate the potential of isolated bacteria endophytes as biocontrol agents against Xoo. In vitro microbiological techniques was used to observe phenotypic functionality of these endophytes to supress the bacterial pathogen and genome analysis approach to identify the bacterial endophytes.

\subsection{The Distribution of Endophytes}

Based on the study, a total of 233 endophytes were successfully isolated from surface-sterilized leaves and roots of rice plant from three different rice field in Kedah, Kelantan and Pulau Pinang, Malaysia. The number of isolated endophytic bacteria were varied from different rice field and part of rice plant (Figure 1). Kedah rice field demonstrated the highest number of isolated endophytes isolates from root with $77.78 \%$ while leaves in Pulau Pinang showed the highest number of endophytes isolates from leaves samples with $34.78 \%$.

\subsection{In vitro Screening}

All endophytes isolates were screened for their activity against Xanthomonas oryzae pv. oryzae (Xoo), 


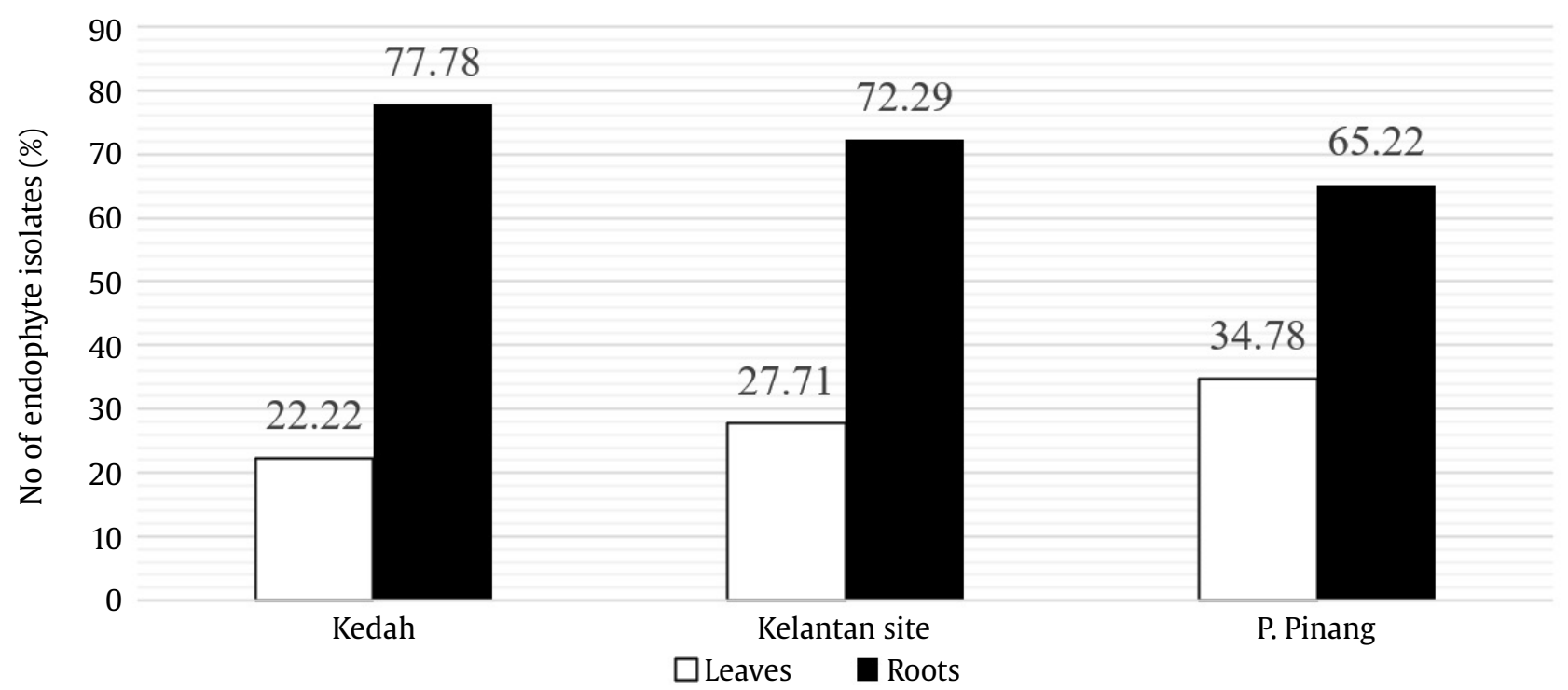

Figure 1. The percentage of endophytic bacteria isolated from the respected rice plant tissues

the causal agent of bacterial leaf blight disease. Out of 233 isolated endophytes, only 17 showed positive result in terms of inhibitory against Xanthomonas oryzae pv. oryzae. Based on the 16S rRNA sequences, all 17 endophytes were closely related to Enterobacter sp., Geobacillus thermoparaffinivorans, Gamma proteobacterium, Pseudomonas fluorescent, Bacillus subtilis, and Bacillus cereus.

All the 7 identified species of endophytes were found to have antagonism properties against test pathogens. There was a significant difference $(p<0.05)$ among potential endophytes against Xoo according to Tukey's test (Table 1). Maximum diameter of

Table 1. Antibacterial activity of endophytes against bacterial leaf blight.

\begin{tabular}{lc}
\hline Endophytes & $\begin{array}{c}\text { Diameter of } \\
\text { inhibition zone }(\mathrm{mm})\end{array}$ \\
\hline Enterobacter sp. & $30.5 \pm 0.58^{\mathrm{a}}$ \\
Geobacillus thermoparaffinivorans & $35.0 \pm 0.00^{\mathrm{b}}$ \\
Gamma proteobacterium & $31.3 \pm 0.58^{\mathrm{c}}$ \\
Pseudomonas fluorescent & $35.0 \pm 0.00^{\mathrm{d}}$ \\
Bacillus subtilis & $33.3 \pm 0.58^{\mathrm{e}}$ \\
Bacillus cereus & $32.3 \pm 0.58^{\mathrm{f}}$ \\
\hline
\end{tabular}

inhibition was observed on Pseudomonas fluorescent and Geobacillus thermoparaffinivorans with $35 \pm 0.00$ mm each (Table 1 ).

\subsection{Effects of Endophytes in Suppression of Disease under Glasshouse Experiment}

The glasshouse screening was performed to all the potential endophytes and its showed different effect on development of bacterial leaf blight disease in rice (Table 2). Generally, all potential endophytes demonstrated a substantial reduction of bacterial leaf blight disease compared to control. Endophyte Geobacillus thermoparaffinivorans and Bacillus sp. showed the highest disease control efficacy, $83.49 \%$ and $81.56 \%$ respectively. The lowest suppression efficiency was observed in Enterobacter sp. with $33.01 \%$.

\section{Discussion}

Endophytic is a microorganism that live within the plant tissues without causing any harms to the host plant. Endophytic bacteria likely utilize plant

Table 2. Effects of potential endophytes in controlling bacterial leaf blight disease in glasshouse experiment

\begin{tabular}{lcc}
\hline Treatment & Disease severity $(\%)$ & Suppression efficacy $(\%)$ \\
\hline Xoo & 76.30 & - \\
Xoo + Chemical bactericide & & \\
Xoo + Enterobacter sp. & 57.78 & 24.27 \\
Xoo + Bacillus subtilis & 14.07 & 81.56 \\
Xoo + Bacillus cereus & 36.30 & 52.42 \\
Xoo + Gamma proteobacterium & 43.70 & 42.73 \\
Xoo + Pseudomonas fluorescent & 51.11 & 33.01 \\
Xoo + Geobacillus thermoparaffinivorans & 12.60 & 83.49 \\
\hline
\end{tabular}


tissues through several entry sites (Hardoim et al. 2015). The opening or cracks at the root, stomata, hydathodes and wound at the shoots are determined as main entry point of endophytes to enter the host plant (Naveed et al. 2014). In the present study indicate that, root part showed a high colonization of endophytic bacteria compare to leaves part in three rice field. Similar finding also was reported by Kandel et al. (2017) which showed a high distribution of endophytes bacteria isolated from root parts. This factor influences by the soils condition itself dominated by many microorganisms and the roots endophytes are recruited from the soils, then move to the stems and leaves (Chi et al. 2005; Liu et al. 2017). Furthermore, the physical and chemical of soils, nutrient availability and moisture directly affected the endophytes bacterial communities at roots and also is a place for complex interaction between the plant and surrounding soil microorganisms because plant needs great variety of bacteria to facilitate the uptake of nutrients, water uptake and utilization of organic pools (Aletaha et al. 2018).

Previous researcher find out that endophytic bacteria have several potential applications in drug discovery and pharmaceutical (Strobel 2006; Guo et al. 2008). Extensive field research has addressed endophytic bacteria might enhance biocontrol efficacy and consistency in performance since there are an interaction between plant and microbes and these interactions contribute to the plant health for better growth and development, soil fertility as well as yield (Souza et al. 2015).

Biocontrol is one of the most effective alternate strategies that can be used to treat the bacteria caused plant diseases (Pal and Gardener 2006). Biological control of plant diseases can be defined as the process in which the pathogenic bacteria that caused plant disease will be inhibit or impacting their activities by one organism (Dicklow 2013). Endophytic bacteria have shown effective control of disease such as Bacillus sp., Acinetobacter sp., Bacillus licheniformis, and Pseudomonas putida (Palaniyandi Velusamy et al. 2013), Burkholderia cepacia, Bacillus amyloliquefaciens, Staphylococcus warneri, Panteo vagans, Pantoea sp., Oceanobacillus oncorhynchi, and Paenibacillus cineris (Azman et al. 2017).

Two hundred and thirty-three endophytic bacteria were isolated from leaves and roots of rice plant but only 17 endophytes showed positive antagonistic activity against Xanthomonas oryzae. The potential endophytes when identified by molecular 16s rRNA amplication were Enterobacter sp., Geobacillus thermoparaffinivorans, Gamma proteobacterium, Pseudomonas fluorescent, Bacillus subtilis, and Bacillus cereus. Similarly, Walintang et al. (2017) and Liu et al. (2017) were also reported the presence of Bacillus sp., Pseudomonas sp., and Gamma proteobacterium endophytes isolates from rice plants. The results of antagonistic activity showed Geobacillus thermoparaffinivorans and Pseudomonas fluorescent seem to effectively inhibit the growth of Xanthomonas oryzae with $35 \mathrm{~mm}$ in diameter of inhibition zone. Similarly, according to Durairaj et al. (2017), Pseudomonas and Bacillus strain are found to have broad spectrum of antagonistic activity against bacterial phytopathogens. Besides that, the ability of Pseudomonas fluorescent to suppress pathogens is mainly connected to their secondary metabolites secretion such as hydrogen cyanide phenazines phloroglucinols, pyrrolnitrin, and pyoluteorin (Palleroni 2005; Hass and Defago 2005; Muller et al. 2018).

The potential endophytes then was proceed for glasshouse evaluation. Glasshouse evaluation included assessment of effects due to the local environment, seasonal variation and crop management practice such as pesticide use, which cannot be assessed in the laboratory experiment (A. Nicholas et al. 2007). Bacillus subtilis was not showing highest inhibitory effect when tested in laboratory, but some significant effects were detected in the glasshouse evaluation when Geobacillus thermoparaffinivorans and Bacillus subtilis showed highest of disease control efficacy by $83.49 \%$ and $81.56 \%$. As far is our concern, this is the first study reported the efficiency of Geobacillus sp. against Xoo. According to Hussein et al. (2015), Geobacillus sp. are grouped together as Bacillus sp. but then being reclassification according to the thermophile's characteristic to a separate genus, Geobacillus sp. Hussein et al. (2015) reported the use of Geobacillus sp. in controlling and protecting plants against Fusarium wilt, the wide spread plant pathogen. Therefore, the result in present work suggested Geobacillus thermoparaffinivorans together with Bacillus sp. to be developed and commercialize as promising biocontrol agent in agriculture sector in future.

\section{Conclusion}

Present study showed the potential of Geobacillus thermoparaffinivorans and Bacillus subtilis endophytes for 
bacteria leaf blight disease reduction. Further research is needed for the identification of secondary metabolites production of both isolates and its effectiveness as biocontrol agent against other important pathogens of rice as well as its efficacy in the pot trial.

\section{Acknowledgements}

The authors would like to express their gratitude to the Universiti Teknologi MARA for the facilities, support and financial aids. The author also thanks to MARDI for facilities at Seberang Prai and guidance throughout the research experiment.

\section{References}

A Nicholas et al. 2007. The role of laboratory, glasshouse and field scale experiments in understanding the interactions between genetically modified crops and soil ecosystems: a review of the ECOGEN project. Pedobiologia 51:251-260. DOI:10.1016/j. pedobi.2007.04.008

Abdulkadir M, Waliyu S. 2012. Screening and isolation of the soil bacteria for ability to produce antibiotics. European Journal of Applied Sciences 4:211-215. DOI:10.5829/idosi.ejas.2012.4.5.2011

Aktar et al. 2009. Impact of pesticides use in agriculture: their benefits and hazards. Interdisciplinary toxicology 2:1-12.

Aletaha et al. 2018. A survey on endophytic fungi within roots of Chenopodiaceae species under different environmental conditions. Mycosphere 9:618-634. DOI:10.5943/mycosphere $/ 9 / 4 / 1$

Azman et al. 2017. Screening of bacteria as antagonist against Xanthomonas oryzae pv . oryzae, the causal agent of bacterial leaf blight of paddy and as plant growth promoter. Journal of Experimental Agriculture International 16:1-15. DOI:10.9734/JEAI/2017/33697

Chi et al. 2005. Ascending migration of endophytic rhizobia from roots to leaves, inside rice plants and assessment of benefits to rice growth physiology. Appl Environ Microbiol 71:7271-7278. DOI:10.1128/ AEM.71.11.7271-7278.2005

Dicklow MB. 2013. Biological Control of Plant Diseases. The Centre for Agriculture, Food and the Environment. Available at: http://ag.umass.edu/vegetable/factsheets/biological-control-of-plant-diseases [Date accessed: 29 August 2019]

Durairaj et al. 2017. Potential for plant biocontrol activity of isolated Pseudomonas aeruginosa and Bacillus stratosphericus strains against bacterial pathogens acting through both induced plant resistance and direct antagonism. FEMS Microbiology Letters 364:18. DOI:10.1093/femsle/fnx225

Guo et al. 2008. Bioactive natural products from endophytes: a review. Prikl Biokhim Mikrobiol 44:153-158.

Haas D, Défago D. 2005. Biological control of soil-borne pathogens by fluorescent pseudomonads. Nat Rev Microbiol 3:307-319. DOI:10.1038/nrmicro1129

Hallmann et al. 1997. Bacterial endophytes in agricultural crops. Canadian Journal of Microbiology 43: 895-914.

Hardoim et al. 2015. The hidden world within Plants: ecological and evolutionary considerations for defining functioning of microbial endophytes. Microbiol Mol Biol Rev 79:293-320.

Hogg AC et al. 2010. Monitoring Fusarium crown rot populations in spring wheat residues using quantitative real-time polymerase chain reaction. Phytopathology 100:49-57.
Hussein et al. 2015. The genus Geobacillus and their biotechnological potential. Advances in Applied Microbiology 92:1-48.

Kandel et al. 2017. Bacterial endophyte colonization and distribution within plants. Microorganisms 5:9-11. DOI:10.3390/microorganisms5040077

Kathleen et al. 2006. Identifying unknown bacteria using biochemical and Molecular Methods. Saint Louis.

Kim et al. 2012. Introducing EzTaxon-e: a prokaryotic 16S rRNA gene sequence database with phylotypes that represent uncultured species. International Journal of Systematic and Evolutionary Microbiology62:716-721.

Krishnan N, Muthurajan R. 2014. Management of bacterial leaf blight disease in rice with endophytic bacteria. World Applied Sciences Journal 28:2229-2241.DOI:10.5829/ idosi.wasj.2013.28.12.2009

Liu et al. 2017. Inner plant values: diversity, colonization and benefits from endophytic bacteria. Front Microbiol 8: 2552. DOI:10.3389/fmicb.2017.02552

Muller et al. 2018. Antagonistic potential of Fluorescent Pseudomonads colonizing wheat heads against mycotoxin producing alternaria and Fusaria. Frontiers in microbiology 9:2124. DOI:10.3389/ fmicb.2018.02124

Naveed et al. 2014. The endophyte Enterobacter sp. FD17: a maize growth enhancer selected based on rigorous testing of plant beneficial traits and colonization characteristics. Biol Fertil Soils 50:249-262. DOI: 10.1007/s00374-013-0854-y

Pal KK, B McSpadden Gardener. 2006. Biological control of plant pathogens the plant health instructor. DOI:10.1094/PHI-A-2006-1117-02.

Palaniyandi et al. 2013. Rhizosphere bacteria for biocontrol of bacterial blight and growth promotion of rice. Rice Science 20:356-362. DOI:10.1016/S16726308(13)60143-2

Palleroni NJ 2005. Genus I. pseudomonas migula 1894. In: Brenner DJ, Krieg NR, Staley JT(Eds.). Bergey's Manual of Systematic Bacteriology, The Proteobacteria, Part B, The Gammaproteobacteria, 2nd. New York: Springer. pp. 323-379. 10.1002/9781118960608.gbm01210

Raweekul W, Wuttitummaporn S. 2016. Plant growth promotion by endophytic bacteria isolated from rice (Oryza sativa). Thammasat International Journal of Science and Technology 21:7-17. DOI:10.14456/ tijsat.2016.2

Schulz B, Boyle C. 2006. What are endophytes? In: Schulz BJE, Boyle CJC, Sieber TN(Eds.). Microbial Root Endophytes. Berlin:Springer. pp 1-13.

Schulze-lefert P, Robatzek S. 2006. Plant pathogens trick guard cells into opening the gates. Cell 126:831-834. DOI:10.1016/j.cell.2006.08.020

Shrestha et al. 2016. Biological control activities of iceassociated Bacillus sp. strains against sheath blight and bacterial panicle blight of rice. PLoS ONE 11:e0146764.

Souza $\mathrm{R}$ et al. 2015. Plant growth-promoting bacteria as inoculants in agricultural soils. Genetics and Molecular Biology 38:401-419. DOI:10.1590/S1415475738420150053

Strobel G. 2006. Harnessing endophytes for industrial microbiology. Curr Opin Microbiol 9:240-244. DOI:10.1016/j.mib.2006.04.001

Walitang et al. 2017. Characterizing endophytic competence and plant growth promotion of bacterial endophytes inhabiting the seed endosphere of Rice. BMC Microbiol 1-13. DOI:10.1186/s12866-017-1117-0

Yasmin et al. 2017. Biocontrol of bacterial leaf blight of rice and profiling of secondary metabolites produced by Rhizospheric Pseudomonas aeruginosa BRp3. Front Microbiol 8:1-12. DOI:10.3389/fmicb.2017.01895 